\title{
Investigating the Relationship between the Effects of Motivation, Personal Development and Basic Computer Usage Upon the Student Success in Distance Education Via the Structural Equation Modeling
}

\author{
Hakan KÖR* \\ Distance Education Centre, Hitit University, Çorum, Turkey
}
Hasan ERBAY
Engineering Faculty, Computer Engineering, Kırlkkale University, Kırlkkale, Turkey

Emre DÜNDER

Faculty of Science, Ondokuz Mayls University, Samsun, Turkey

\section{Emre DEMIR}

Medicine Faculty, Hitit University, Çorum, Turkey

\begin{tabular}{|c|c|}
\hline Article history & Objective. This study determined the factors affecting the academic \\
\hline $\begin{array}{l}\text { Received: } \\
27.05 .2016\end{array}$ & $\begin{array}{l}\text { success of students receiving distance education and examines the } \\
\text { relationships between these factors. As a result of the factor analysis, the }\end{array}$ \\
\hline $\begin{array}{l}\text { Received in revised form: } \\
23.07 .2016\end{array}$ & $\begin{array}{l}\text { relationships between the variables of motivation, personal development } \\
\text { and basic computer usage that were separated into groups were tested } \\
\text { using the structural equation modeling. Methods. A } 5 \text { point likert scale }\end{array}$ \\
\hline $\begin{array}{l}\text { Accepted: } \\
24.07 .2016\end{array}$ & $\begin{array}{l}\text { that was prepared according to expert opinion was applied to the sample } \\
\text { group consisting of students receiving associate degree education at }\end{array}$ \\
\hline Key words: & Kırıkkale University Distance Education Center (KUZEM). The study \\
\hline $\begin{array}{l}\text { Distance Education, Structural } \\
\text { Equation Modeling, } \\
\text { Motivation, Academic Success. }\end{array}$ & $\begin{array}{l}\text { hypothesis presented a relationship between the variables of motivation, } \\
\text { personal development and basic computer usage that were asserted to } \\
\text { have an effect upon the student success. The hypothesis test was } \\
\text { performed using the structural equation modeling. Findings. This part } \\
\text { involves the results of the structural equation modeling that tested the } \\
\text { reliability analysis, factor analysis and the study hypothesis. Results. (1) } \\
\text { Variables in the variable group involving questions aimed at students in } \\
\text { the process of education like "have you received distance education?", } \\
\text { "are efficient materials being used" and "what is your level of using the } \\
\text { presentation program", (2) Among the variable groups whose effects } \\
\text { upon the student success were examined, there is a two-sided and } \\
\text { significant relationship between the motivation and the personal } \\
\text { development level, (3) There is no significant relationship between the } \\
\text { basic computer usage and the personal development. }\end{array}$ \\
\hline
\end{tabular}

Correspondence: hakankor19@gmail.com 


\section{Introduction}

Scientists have defined the concept of learning in similar ways. Learning is a change of thoughts, perceptions and behaviors caused by the interaction of individuals with the environment (Morgan, 1993). In other words, learning contains behavioral changes that are caused by life activities and continue lifelong (Özden, 2002). Being an efficient process that is performed in an audial, visual or a practical way; learning has become even more important today due to its continuity. Because one of the most important functions being required by our era is lifelong learning. Educational activities could formally be provided at educational institutions; however, the developing technology enables us to realize the function of teaching via various teaching methods (Kör, H. et al. 2013).

Individuals who had been unable to receive education for various reasons in the past could register to associate degree, undergraduate or postgraduate programs under proper conditions and maintain their education. Distance education provides a equality of opportunity for individuals via various possibilities.

\section{Distance education is an educational method:}

-Involving individuals who have been unable to receive education via traditional methods,

-Separating the teacher and the learner group into different environments,

-Providing a flexible time and age for learning,

-Involving carefully prepared units and contents,

-Using technologies such as printed materials, radio, television and computers as learning instruments,

-Providing a high-level of communication between the teacher and the learner group.

Universities providing distance education, programs being opened increases the number of students also brings questions about the efficiency of education. Researchers maintain their studies to develop online activities (Clark and Kwinn, 2007; O'Neil, 2005, 2008; Reiser and Dempsey 2012). It is very important to know the values and the effect of e-learning in terms of evaluating the e-learning process and making the society understand the process (Raspopovic et al., 2014).

Let's have a look at the concepts of motivation, personal development and basic computer knowledge that are asserted to have an effect upon the student success in the process of distance education.

\section{Motivation}

According to a number of researchers, motivation is an effective factor for the school success (Harter and Connell, 1984; Ryan et al., 1983). Motivation could be evaluated as a series of powers in achieving some certain goals and increasing the performance (Khan et al., 2010). Rizwan and Usman suggest that (2010) it is the sum of various methods of directing and cementing our activities in order to obtain some of our special ambitions. Motivation is actually what is hidden in the heart and the mind of others (Ford, 1992).

\section{Personal Development}

Personal development of individuals is affected by genetics, environmental, operational (behavioral) and stochastic factors. (Fraley and Roberts, 2005). According to the 
personality psychology, personality is shaped at early ages and continues to change lifelong in a significant way (Roberts, B. et al., 2010).

The features that are known as five great features and are obtained from the repeated analyses of factor features are as follows; extroversion, neuroticism, experience, conventionalism, inner conscience and being open for improvement (Dan and Bradley, 2010).

There are many studies on the effect of subjects being investigated in studies that are conducted in different disciplines upon the personal development or the opposite. The personal development being mentioned in this study is considered the personal and social learning levels of individuals.

\section{Basic Computer Usage}

Basic computer usage is defined as the general computer usage, word processor program, accounting statement and database program usage (Mindebele \& Hlophe, 2007). This study investigated the computer usage levels of students in an attempt to determine whether or not their basic computer levels affected their success in distance education.

\section{Literature Review}

According to a number of researchers, motivation significantly determines the student outputs like self-efficacy, course participation (Deci and Ryan, 1985; Nurmi and Aunola, 2005; Opdenakker and Maulana, 2010) and academic success (i.e., Boggiano, 1998; Deci and Ryan, 2002; Den Brok et al. 2010; Lepper et al., 2005).

Among the interventions aimed at understanding the learning behaviors of students in Math education, emotional interests come into the forefront. Especially increasing the motivation of students in Math classes is very important for both students and teachers. Regarding this subject, 2 types of tests were applied to 321 sixth grade students for measuring their motivation and other emotional structure in Math. Examining the relationship between the emotional structure, motivation and both the performance and interest of students in Math by using the structural equation modeling; it was observed that the success performance and interest had a negative effect upon the failure anxiety, self-efficacy and success goals (Pantziara et al., 2015).

In their study, (Balog and Pribeanu, 2010) claim that motivation is an important factor in the process of modern education and a high level of motivation is a prerequisite for success. They also assert that using the augmented reality technologies may increase the participation and interest of students in the learning process. They use the structural equation modeling to measure the external and internal motivation of students toward the augmented reality model (ARTP). According to the results, the perceived practicality and student interest have a behavioral tendency for the ARTP usage. According to the structural equation modeling test, what makes ARTP important is its appeal to students rather than its practicality.

Another study using the structural equation modeling examined the relationship between the variables affecting the acceptance of synchronous e-learning technology and suggested the augmented technology acceptance (Kang and Shin, 2015). Two hunderd and fifty one students participated in the questionnaire being applied to university students and the hypotheses was tested via the structural equation modeling. As a result of the test; it was determined that while the systematic course content had no effect upon the synchronous elearning technology acceptance of students, self-efficacy, standard rules and the system accessibility were observed to have an effect. 
In this study we examine the motivation, attitudes and academic participation in the success of 8th grade students in Math and Science (Singh Et al., 2002). It was determined that even though the cognitive skills and home experiences of students had significantly determined the success in recent years, emotional variables played a key role in the success and sustainment of Math and Science. The researchers tested the student success in Math and Science education and the hypothesis relations of 2 motivation factors (attitude factor and academic participation) by using the structural equation modeling. According to the results, both the student attitude and the academic time being spent on Math and Science education were observed to have a positive effect upon motivation.

In Mexico, a study was conducted in an attempt to enable the students receiving postgraduate education ( 2 formal, 1 distance education) to complete their education and remove the factors hindering success. Being grounded on expectation values, the study examined the motivation and social interactions of students. Personal characteristics and environmental factors were investigated to increase the blunt motivation values of students. It was determined that while high income and career development perceptions had a positive effect upon the motivation of students; high expectations, time limitations, miscommunication and insufficient support of student advisors had a negative effect (Patricia, 2012).

Examining the studies, investigating the factors that affect student success in both distance and formal education, it was observed that the motivation and personal development perceptions of students affect one another. It is also observed that students with a higher personal efficacy, in other words a higher self-efficacy perception have higher levels of motivation as well.

The literature involves some studies aimed at investigating the effect of concepts like computer literacy or digital literacy upon the academic success of students. Computer literacy or e-skills comprise competences that are recommended for analytical problem-solving, writing skills, social awareness, personal responsibility and graduation from formal education. A study was applied to 1st grade students receiving distance education in order to evaluate their e-skills (Mabila, 2013). The study used online skill simulation for determining the performances of students and categorizing their digital efficacies. The e-skills were evaluated by simulating the questions about using the Microsoft Word documents, Powerpoint presentations, Microsoft Excel, e-mails and the internet. The performances and e-skills of students were graded in 4 stages. (1) digital awareness, (2) digital literacy, (3) digital efficacy, (4) digital speciality. Besides, the questionnaire being applied, the information was collected from the participants above 2 dimensions. Firstly the information of students regarding the office, e-mail and the internet usage were recorded, then the information being collected from the students was confirmed via an online evaluation. The results show that while some participants are categorized as digital experts, others considerably lack core knowledge about computer usage. According to the study, there are differences between the e-skills of university students that have started distance education. In order to consider these differences in the student success, some suggestions have been made for e-learning designers, academicians and educational policy makers.

\section{Method}

This part of the article involves the stages of sample selection, conceptual model of study, research hypotheses, definition of study group, data collection and data analysis.

\section{Sample}


The study sample consisted of students receiving education at Kırıkkale University Distance Education Center Department of Computer Programming. In this study, the data of 80 students, who were randomly selected from students answering all the questions in the online questionnaire that was applied to 200 students, were exposed to the analysis procedures.

\section{Research Hypothesis}

In this study, the hypothesis to be taken as a criteria was tested for the distance education student group. According to the data that was acquired as a result of the study, vocational high schools providing distance and formal associate degree education at universities in Turkey were generalized.

H1: There is a significant relationship between the variables of motivation, personal development and basic computer usage levels that affect the student success.

\section{Data Collection Tool: Preparation and Application}

In the study, a questionnaire was used as the data collection tool. In the first stage of the study, a questionnaire involving questions in various categories was applied. The questionnaire was applied to students on the web. The questionnaire being prepared was loaded onto the web site of the university, and open to access on the address http://www.eskisungurlumyo.hitit.edu.tr/distanceeducationsurvey/ (Kör, 2013).

Before preparing the questions in the questionnaire that was applied to different student groups receiving the same education in terms of curriculum via different educational methods we determined the priorities regarding from what aspects the distance education would be compared and whether or not it would have considerable meaning for the study being conducted. While preparing the questions in the questionnaire, we received the opinions of expert instructors in the field of educational sciences and prepared the questions and options in accordance with the questionnaire preparation rules. In the questionnaire involving a five point likert questions, the questions were categorized according to the features to be measured and then they were applied to students.

Among the students that participated in the questionnaire and completed the questionnaire, answers of 80 students that were considered valid and selected randomly were exposed to analysis procedures. These procedures were performed using the SPSS (version 22.0) package software.

\section{Findings}

This part involves three important stages being applied for obtaining the results: reliability analysis, factor analysis and structural equation modeling.

\section{Reliability and Factor Analysis}

Cronbach Alpha reliability analysis was applied in an attempt to measure the reliability of the questionnaire. While determining the reliability of the scale, the Cronbach alpha $(\alpha)$ coefficient was preferred to be above 0.70 (Büyüköztürk, 2005, 2011). As well as 
the reliability of the scale, we separately calculated the reliability coefficients that would be acquired in case of deleting the scale items.

Examining the results, 29 questions being applied to students was reduced to 24 questions by eliminating the questions with a lower reliability, as a result of the reliability analysis and the reliability coefficient of the scale was determined as 0.803 . Accordingly, the questionnaire was determined to be reliable at the rate of $80.3 \%$ (Table1).

A factor analysis was applied in an attempt to reduce the dimension of the remaining 24 questions in the scale. According to the rotated composites matrix, 5 more questions under the sole factor were excluded after the second factor analysis that was performed by excluding 7 questions that did not match the factor analysis, and at the end of the final factor analysis a totally of 15 questions were subsumed under 3 factors.

\section{Reliability Analysis}

Table 1. Results of the Reliability Analysis

\begin{tabular}{cc}
\hline \multicolumn{2}{c}{ Reliability Statistics } \\
\hline Cronbach's Alpha & N of Items \\
0.803 & 24 \\
\hline
\end{tabular}

Examining Table 1; according to the Cronbach's Alpha value of 0.803, the questionnaire has a high level of reliability.

\section{Factor Analysis}

Table 2. Test Values of the Factor Analysis

\begin{tabular}{|c|c|c|}
\hline \multicolumn{2}{|c|}{ Kaiser-Meyer-Olkin Sample Adequacy Merit } & 0.872 \\
\hline \multirow{3}{*}{ Bartlett's Sphericity Test } & Chi-square Statistics & 1189.448 \\
\hline & sd & 120 \\
\hline & Significance & 0.001 \\
\hline
\end{tabular}

Table 2 shows the results of the Bartlett's Sphericity Test and the KMO sample adequacy merit regarding the answers given to the distance education scale. Examining the results of the Bartlett's Sphericity Test, a significant correlation was determined between the variables according to the significance value $(\mathrm{p}<0.05)$. According to the KMO statistics, the scale was determined to be convenient for the factor analysis approximately at the rate of $87.2 \%$.

Table 3. Test Values of the Factor Analysis

\begin{tabular}{ccccc}
\hline \multirow{2}{*}{ Component } & Eigenvalue & \multicolumn{4}{l}{ Total Sum of the Squares of Loads as a Result of Rotation } \\
\hline & Total & Total & Variance\% & Cumulative \% \\
1 & 5.485 & 4.224 & 26.403 & 26.403 \\
2 & 2.580 & 2.530 & 15.813 & 42.215 \\
3 & 1.155 & 2.466 & 15.414 & 57.630 \\
\hline
\end{tabular}


Examining Table 3, the results of the factor analysis show that there are 3 factors with an eigenvalue greater than 1 . The table does not show the factors with an eigenvalue smaller than 1. The acquired factor explains 57,630 of the total variability.

Table 4. Item Loads of the Factor Analysis

\begin{tabular}{|c|c|c|c|}
\hline \multirow[t]{2}{*}{ Item (Abbreviated) } & \multicolumn{3}{|c|}{ Factor } \\
\hline & 1 & 2 & 3 \\
\hline Q8: Evaluation and content are convenient (M1) & 0.805 & & \\
\hline Q6: Course contents meet the needs (M2) & 0.743 & & \\
\hline Q9: Convenient for a formal evaluation (M3) & 0.742 & & \\
\hline Q7: Materials are used (M4) & 0.735 & & \\
\hline Q4: Contents are convenient for the level (M5) & 0.716 & & \\
\hline Q5: Contents are up-to-date (M6) & 0.688 & & \\
\hline Q1: Contents are convenient for the readiness level (M7) & 0.594 & & \\
\hline Q3: I will find a good job (M8) & 0.460 & & \\
\hline Q16: Your level of using the accounting statement program (B1) & & 0.843 & \\
\hline Q17: Your level of using the presentation program (B2) & & 0.843 & \\
\hline Q15: Your level of using the word processor program (B3) & & 0.749 & \\
\hline Q18: Your level of using the database program (B4) & & 0.696 & \\
\hline Q11: Lifelong learning (K1) & & & 0.806 \\
\hline Q13: Personal learning (K2) & & & 0.768 \\
\hline Q12: There is an equality of opportunity (K3) & & & 0.636 \\
\hline
\end{tabular}

Table 4 shows the rotated composites matrix regarding all the questions. This matrix indicates under which factor each question is gathered. The table also shows the factor of each question and the correlation values between them.

Table 5. Factor Names

\begin{tabular}{ll}
\hline Factor & Factor name \\
\hline 1. Factor & Motivation \\
2. Factor & Basic Computer Usage \\
3. Factor & Personal Development \\
\hline
\end{tabular}

According to the result of the factor analysis, Table 5 shows the names of 3 factors.

\section{Conceptual Model of the Study}

The dimensions that are asserted to affect the academic success of students are respectively as follows: motivation levels, personal development conditions and basic computer usage skills of students receiving distance education.

Figure 1 shows the relationship between the factors that are asserted to affect the academic success of students in the process of distance education. This figure also forms the conceptual model of the study. The study hypothesis was developed based on this model. 


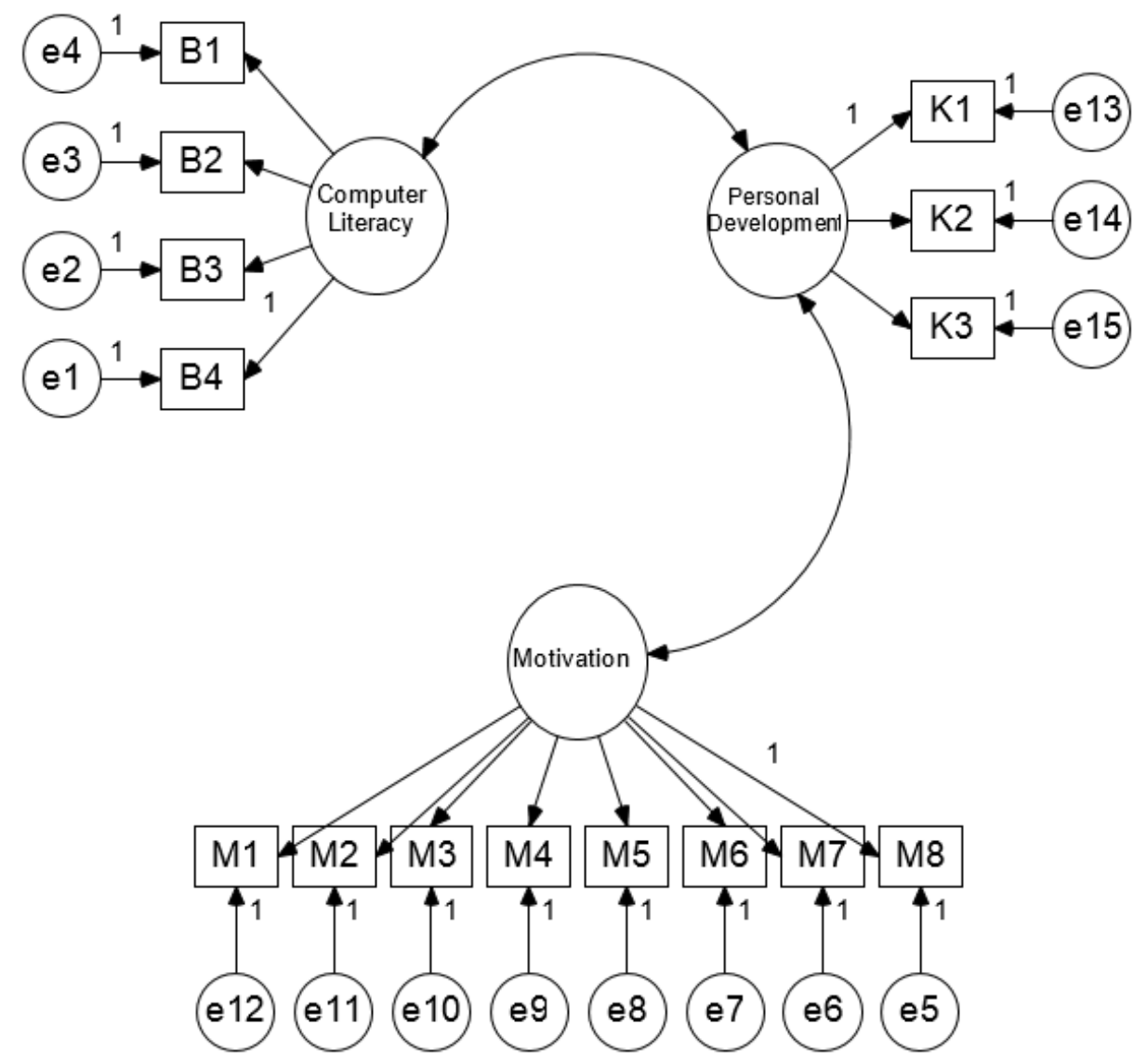

Fig. 1. Conceptual Model of the Study

In the conceptual model diagram of the study being displayed in Figure 1, the variable names under the factors of basic computer knowledge, personal development and motivation are depicted in Table 5.

\section{Structural Equation Modelling}

In this part, we tested the hypotheses regarding 3 factors that were determined as a result of the Factor Analysis, which was asserted to affect the academic success of students.

Table 6. Standardized Regression Coefficients regarding the Measurement Model

\begin{tabular}{lllrcc}
\hline & & & Estimate & StandartError & Sig. \\
\hline B4 & $<---$ & Basic Computer Usage & 1.000 & & \\
B3 & $<---$ & Basic Computer Usage & 1.292 & 0.175 & 0 \\
B2 & $<---$ & Basic Computer Usage & 1.302 & 0.175 & 0 \\
B1 & $<---$ & Basic Computer Usage & 1.140 & 0.172 & 0 \\
M8 & $<--$ & Motivation & 1.000 & & \\
M7 & $<---$ Motivation & 1.162 & 0.201 & 0 \\
M6 & $<---$ & Motivation & 1.329 & 0.227 & 0 \\
M5 & $<---$ & Motivation & 1.545 & 0.256 & 0 \\
M4 & $<---$ & Motivation & 1.745 & 0.269 & 0
\end{tabular}




\begin{tabular}{|c|c|c|c|c|c|}
\hline M3 & $<---$ & Motivation & 1.646 & 0.268 & 0 \\
\hline M2 & $<---$ & Motivation & 1.623 & 0.259 & 0 \\
\hline M1 & $<---$ & Motivation & 1.277 & 0.237 & 0 \\
\hline K1 & $<---$ & Personal Development & 1.000 & & \\
\hline K2 & $<---$ & Personal Development & 0.989 & 0.131 & 0 \\
\hline K3 & $<--$ & Personal Development & 0.900 & 0.123 & 0 \\
\hline
\end{tabular}

The table above shows the standardized regression coefficients regarding the measurement model. According to the results in the table, all the variables have a significant effect upon latent variables $(p<0.05)$. According to the standardized regression coefficients, each latent variable determines the effect levels of variables affecting them. These results show that K1 is the variable with the highest effect upon personal development, M4 upon motivation and B2 upon basic computer usage.

Table 7. Standardized Regression Coefficients regarding the Structural Modeling

\begin{tabular}{lccccc}
\hline & & & Estimate & Standart Error & \multicolumn{1}{c}{ Sig. } \\
\hline Basic Computer Usage & $<->$ & Personal Development & 0.096 & 0.050 & 0.055 \\
Motivation & $<->$ & Personal Development & 0.292 & 0.064 & 0 \\
\hline
\end{tabular}

The table above shows the standardized regression coefficients regarding the structural modeling. According to these results, there is a two-way and significant relationship between motivation and personal development $(\mathrm{p}<0.05)$. On the other hand, there is no significant relationship between basic computer usage and personal development $(\mathrm{p}>0.05)$.

Table 8. Fit Indexes Being Calculated for the Structural Equation Modeling

\begin{tabular}{lcc}
\hline Fit Measure & Goodness of Fit Values & Abbreviations \\
\hline$\chi^{2} / \mathrm{sd}$ & 1.449 & CMIN/df \\
Goodness of fit index & 0.913 & GFI \\
Normed fit index & 0.883 & NFI \\
Incremental fit index & 0.960 & IFI \\
Comparative fit index & 0.960 & CFI \\
Root mean square error of approximation & 0.049 & RMSEA \\
Hoelter 0,05 index & 161 & HFIVE \\
Hoelter 0,01 index & 177 & HONE \\
\hline
\end{tabular}

The table above shows the fit indexes being calculated for the structural equation modeling. Examining the fit indexes, the division of the chi-square test statistics into the degree of freedom is lower, smaller than 5. The values GFI, NFI, IFI and CFI are observed to be close to 1 . The value RMSEA is smaller than 0,05 and the Hoelter indexes show that the sample dimension of the study is very good. According to all the fit indexes, the structural equation modeling has a good fit.

\section{Conclusion And Discussion}

In this study, the hypothesis $\mathrm{H} 1$ that is asserted to affect the student success was analyzed via the method of structural equation modeling. As a result of the analysis, 
examining the effect of three variables as motivation, personal development and basic computer usage upon the student success; a two-way and significant relationship was determined between the motivation and personal development of students. In other words, students with higher levels of motivation were observed to also have higher levels of personal development. As the relationship was two-way, the students were observed to have lower levels of personal development in reverse cases, in other words when they had lower levels of motivation. Besides, there was no relationship between the basic computer usage skills and the personal development levels of students.

Among the 3 factors that are asserted to affect the student success, the variable $\mathrm{K} 1$ in the factor of personal development (lifelong learning is asserted to dominate the learning process), the variable M4 in the factor of motivation (efficient course materials are asserted to be used in the learning process), and the variable B2 in the factor of basic computer usage (with a higher level of using a presentation program) are observed to be more effective upon the academic success of students.

In this context, regarding this sample of students receiving distance education, it is suggested for the distance education center to lay emphasis on variables that have a greater effect upon success and increase the academic success. For instance, the reason of negativity should be investigated in students presenting negative opinions about the variables K1, M4 and B2.

Some students gave negative answers to the question in the variable K1 regarding " whether or not there are lifelong learning opportunities in the learning process $»$. It is suggested to create environments that would support learning for these students. For instance, it is possible to create amassive online open course system (MOOC) involving rich materials. These MOOC platforms may involve environments with an increased simulation or reality especially for difficult courses where experimental processes are conducted. This will enable the students to watch a difficult course in 3 dimensions and have an interaction via smart phones and other mobile devices.

It is observed that students giving positive answers to the question in the variable M4 regarding «the use of sufficient course materials in the learning process » are more successful than others. Accordingly, it is suggested to review the course materials being used in distance education and prefer more efficient materials. Rather than text-based materials; course materials like videos, audio files, animations and simulations should be presented to the usage of students.

According to the question in the variable B2 aimed at « determining the levels of students to use presentation programs », students with higher levels of using presentation programs were observed to have higher academic success. In this context, it is suggested to give more information to students regarding the usage of presentation programs. It is also suggested to give presentation homework summarizing the subjects to students at the end of course units and enable them to prepare visually rich and easy materials.

This study constitutes a part of variables that have an effect upon the student success in distance education. It is planned to investigate other factors affecting the success by using different variables in future studies.

Besides, the study remains limited with associate degree students receiving distance and formal education at Kırıkkale University Distance Education Center and Vocational High 
School. It is suggested for researchers to extend the study and apply it to larger masses at various universities.

\section{References}

Balog, A. and. Pribeanu, C. (2010). The Role of Perceived Enjoyment in the Students' Acceptance of an Augmented Reality Teaching Platform: a Structural Equation Modelling Approach. Studies In Informatics and Control, 19(3), 319-330.

Boggiano, A.K. (1998). Maladaptive achievement patterns: A test of a diathesis-stress analysis of helplessness. Journal of Personality and Social Psychology, 74, 16811695.

Büyüköztürk, Ş. (2005). Sosyal Bilimler İçin Veri Analizi El Kitabı [Data Analysis Handbook for Social Sciences]. Ankara: Pegema yayıncilık.

Büyüköztürk, Ş. (2011). Veri Analizi El Kitabı [Data Analysis Handbook]. Ankara: Pegem Academy Publishing.

Clark, R. C., \& Kwinn, A. (2007). The new virtual classroom. San Francisco: Pfeiffer.

Dan P. McAdams and Bradley D. Olson. (2010) Personality Development: Continuity and Change Over the Life Course. University Of Chicago. USA: The Annual Review of Psychology.

Deci, E.L., \& Ryan, R.M. (1985). Intrinsic motivation and self-determination in human behaviour. New Yorkn: Plenum.

Deci, E.L., \& Ryan, R.M. (2002). Handbook of self-determination research. Rochester, NY: University of Rochester Press.

Den Brok, P., Van Tartwijk, J., Wubbels, T., \& Veldman, I. (2010). The differential effect of the teacher-student interpersonal relationship on student outcomes for students with different ethnic backgrounds. British Journal of Educational Psychology, 80, 199-221.

Fraley, R. C. \& Roberts, B. W. (2005). Patterns of continuity: A dynamic model of conceptualizing the stability of individual differences in psychological constructs across the life course. Psychological Review 112(1), 60-74.

Ford, M. E. (1992). Motivating humans: Goals, emotions, and personal agency beliefs. Newbury Park, CA: Sage Publications.

Harter, S., \& Connel, J.P. (1984). A model of children's achievement and related selfperceptions of competence, control and motivational orientation. In J.G. Nichols \& M.L. Maehr (Eds.), Advances in motivation and achievement. Greenwich, CT: JAI Press.3, 219-250.

Kang, M. ve Shin, WS. (2015). An Empirical Investigation of Student Acceptance of Synchronous E-Learning in an Online University, Sage Publications. 52 (4), 475-495, USA.

Kör, H., Çataloğlu, E. and ERBAY, H. (2013). Uzaktan ve Örgün Eğitimin Öğrenci Başarısı Üzerine Etkisinin Araştırılması [Distance and Formal Education of Investigation on the Effects of Student Success], Gaziantep University Journal of Social Sciences, Technology Special Issue, 12(2), 267-279.

Kör, H. (2013). Distance Education and Formal Education Versatile - Cross Comparison: Sample of Kırıkkale Üniversity and Hitit Üniversity, Kırıkkale University: Master Thesis.

Lepper, M.R., Corpus, J.H., \& Iyengar, S.S. (2005). Intrinsic and extrinsic motivational orientations in the classroom: Age differences and academic correlates. Journal of Educational Psychology, 97, 184-196. 
Nurmi, J.-E., \& Aunola, K. (2005). Task-motivation During the First School Years: A Personoriented Approach to Longitudinal Data. Learning and Instruction, 15, 103122.

Mabila, J, Ssemugabi, S and Gelderblom, H. (2013). Does Assessing e-Skills Competence at an Open Distance Learning, Higher Education Institution Matter? - A Case in Point, South Africa:Proceedings of the International Conference on e-Learning, 1, 539-544.

Mindebele C.B.S, Hlophe Z.F. (2007). Computer literacy among practical arts teachers in Swaziland Vocational Schools, Journal of Vocational Education \& Training, 53:2, 341-352.

Morgan, C. (1993). Psikolojiye Giriş, Ankara : Hacettepe Üniversitesi Psikoloji Bölümü Yayınları.

O’Neil, H. F. (Ed.). (2005). What works in distance learning: Guidelines. Greenwich, CT: Information Age.

O'Neil, H. F. (Ed.). (2008). What works in distance learning: Sample lessons based on guidelines.Charlotte, NC: Information Age.

Opdenakker, M.-C., \& Maulana, R. (2010). Teacher-student relationships and academicengagement: How do they develop and link? Paper presented at the InternationalConference on Interpersonal Relationships in Education, Boulder, CO.

Özden, Y. (2002). Learning and Teaching. (4. Bask1), Ankara: Pegem Academy Publishing.

Pantziara, M. and Philippou, George N. (2015). International Journal of Science and Mathematics Education, Students' Motivation in The Mathematics Classroom. Revealing Causes and Consequences, 13(2), 385-411.

Patricia, Adelaida Gonzalez-Moreno. (2012). Student Motivation In Graduate Music Programmes: An Examination of Personal and Environmental Factors, England: Music Education Research, 14 (1), 79-102.

Raspopovic, M., Jankulovic A., R., Runic J., Lucic,V. (2014). Factors for e-Learning in a Developing Country: A Case Study of Serbia, The International Review of Research in Open and Distance Learning, 15(3), 1-23.

Reiser, R. A., \& Dempsey, J. V. (Eds.). (2012). Trends and issues in instructional design and technology (NJ: Erlbaum, 3rd ed. Upper Saddle River)

Rivera, J.C., McAlister, M.K. ve Rice, M.L. (2002). A comparison of student outcomes and satisfaction between traditional and web based course offerings. State University of West GeorgiaDistance \& Distributed Education Center. http://www.westga.edu/ distance/ojdla/fall53/rivera53.html, Accessed 26 February 2015.

Rizwan, Q.D., Usman A. (2010). Impact of Reward and Recognition on Job Satisfaction and Motivation: An Empirical Study from Pakistan, International Journal of Business and Management, 5(2), 159-167.

Roberts, B. W., Wood, D., \& Caspi, A. (2010). The development of personality traits in adulthood. In O. P. John, R. W. Robins, \& L. A. Pervi (Eds.). New York : Handbook of personality: Theory and research (3rd ed., pp. 375-398).

Ryan, R.M., Mims, V., \& Koestner, R. (1983). Relation of reward contingency and interpersonal context to intrinsic motivation: a review and test using cognitive evaluation theory. Journal of Personality and Social Psychology, 45, 736-750.

Singh, K., Granville, M., \& Dika, S. (2002) Mathematics and science achievement: Effects of motivation, interest, and academic engagement, USA: Journal Of Educational Research, 95 (6), 323-332. 